School of Finance \& Law

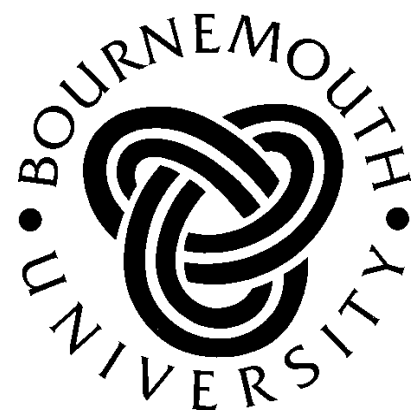

Working Paper Series

The Determinants of Credit Ratings in the United Kingdom Insurance Industry

by

Mike Adams

European Business Management School,

University of Wales Swansea,

Swansea.

Bruce Burton

Department of Accountancy and Business Finance,

University of Dundee,

Dundee.

and

Philip Hardwick

School of Finance and Law,

University of Bournemouth,

Poole.

No. 19.

2000

Bournemouth University, School of Finance \& Law

(Department of Accounting \& Finance), Talbot Campus,

Fern Barrow, Poole, Dorset. BH12 5BB 
Published: 2000 by the School of Finance and Law, Bournemouth University, Talbot Campus, Fern Barrow, Poole, Dorset, BH12 5BB.

For further details contact:

\section{Philip Hardwick}

School of Finance \& Law

Bournemouth University

Fern Barrow

Poole,

Dorset. BH12 5BB

Ph: 00-44-(0)1202-595199

Fx: 00-44-(0)1202-595261

Email: phardwic@bournemouth.ac.uk

ISBN: 1-85899-096-3

Copyright is held by the individual authors.

A catalogue record for this publication is available from the British Library.

\section{Acknowledgements}

We thank Mike Buckle and David Wharrier for their assistance in this study. However, the usual disclaimer applies.

For further information on the working paper series, contact K. Howell, School of Finance \& Law,

Bournemouth University. 


\section{Executive Summary}

\section{The Determinants of Credit Ratings in the United Kingdom \\ Insurance Industry}

Academic researchers have devoted a considerable amount of attention to the activities of credit rating agencies over the past 20 years, focusing in particular on the agencies' potential role in overseeing corporate financial strength and promoting the efficient operation of financial markets. Examinations of credit rating practices has recently extended to the insurance industry, where the complex technical nature of market transactions leads to policyholders, investors and others facing particularly acute information asymmetries at the point-of-sale. Published credit ratings are therefore seen as helping to alleviate imperfections in insurance markets by providing a third party opinion on the adequacy of an insurer's financial health and the likelihood of it meeting obligations to policyholders and others in the future. Although the United Kingdom (UK) insurance market is now one of the five largest in the world, relatively little is known about the practices of the major firms and policy-makers which influence its operations. In particular, whilst the determinants of rating agencies' assessments of United States (US) insurers is well documented, published studies have yet to provide comprehensive evidence about insurance company ratings in the UK. This study attempts to fill this gap by examining the ratings awarded by two of the world's leading agencies - A.M. Best and Standard and Poor (S\&P) - and establishing the extent to which organizational variables can help predict: (i) insurance firms' decision to be rated; and (ii) the assigned ratings themselves.

Our sample of UK data comprises ratings made by A.M. Best and S\&P over the period 1993-1997 for both life and property-liability insurers. The panel data we use is ordinal in nature and is therefore analysed using an ordered probit model. However, because neither A.M. Best or S\&P rate the full population of UK insurance firms our data set is potentially subject to selfselection bias and we therefore extend the model to correct for such problems. In particular, the paper examines the effect of eight firm-specific variables (namely, capital adequacy, profitability, liquidity, growth, size, mutual/stockowner status, reinsurance level, and short/long-term nature of 
business) on the ratings awarded by the two agencies, as well as on insurance firms' decisions to volunteer for the ratings in the first place.

In general terms, our evidence concurs with earlier US findings, and suggests that although the decision to be rated by either of the agencies is largely influenced by a common set of factors, the determinants of the ratings themselves appear to differ. Specifically, our first main finding is that insurers' decisions to be rated by either A.M. Best or S\&P is positively related to surplus growth, profitability and leverage. Second, while we find that A.M. Best's ratings are positively linked to profitability and liquidity, as well as being generally higher for mutual insurers, the findings for S\&P differ substantially. Although liquidity again exerted a positive influence on assigned ratings, the only other statistically significant variable was financial leverage, which had a negative sign.

We believe that the results of our research are of potential importance for companies operating in insurance markets as well as for policy-makers, brokers and others. For example, the evidence that mutual insurers are generally assigned higher ratings than stock insurers suggests that certain publicly-traded insurers, in particular new entrants, might not possess sound financial strength and may require closer regulatory scrutiny than other, more established, insurance firms. In addition, the finding that liquidity has a significantly positive effect on ratings assigned by two of the world's leading credit agencies should provide a measure of confidence about the robustness of the ratings to industry regulators, policyholders and investors in the UK. This could imply that external ratings might eventually play a role in substituting for costly industry regulation. The study concludes that although the factors influencing the decision to be rated by A.M. Best or S\&P are broadly the same, a degree of variability exists in the variables which influence the actual ratings themselves. Insurance company managers should be aware of this when contemplating whether to seek an independent rating and which agency to choose for the assessment. We therefore believe that this study fills an important gap in the literature about key players in the important UK insurance market and provides a basis for the conduct of future research.

\section{Mike Adams, Bruce Burton, Philip Hardwick}




\title{
The Determinants of Credit Ratings in the United Kingdom \\ Insurance Industry
}

\begin{abstract}
This paper examines the determinants of external credit ratings attained by insurance firms in the United Kingdom (UK) and of the decisions by those insurers to seek such an assessment in the first place. Using panel data relating to A.M. Best-rated and Standard and Poor (S\&P)-rated insurers over the period 1993-1997, an ordered probit model with sample selection is employed to test whether firm-specific variables influence both the decision by insurers to be rated and the determinants of the ratings themselves. We find evidence to suggest that the decision to be rated by either A.M. Best or S\&P is positively related to profitability, leverage and growth, but negatively related to company size and the extent of reinsurance. In contrast to the similarity in findings about the decision to be rated, the paper highlights a number of apparent differences in the determinants of the ratings awarded by the two agencies. Our results are shown to be of potential interest to both participants in the insurance industry and policy-makers alike.
\end{abstract}




\section{The Determinants of Credit Ratings in the United Kingdom Insurance Industry}

The role of credit rating agencies in overseeing corporate financial strength and promoting the operation of financial markets has been a topic of intense interest in the finance literature for more than twenty years (e.g., Weinstein, 1977; Pinches and Singleton, 1978; Holthausen and Leftwich, 1986; Cantor and Packer, 1995, 1997). Investigation into credit rating practices has also extended to insurance markets - markets in which the complex technical nature of insurance transactions leads to policyholders, investors and others facing particularly acute information asymmetries at the point-of-sale (Datta and Doherty, 1990). Published credit ratings therefore help to alleviate imperfections in insurance markets by providing interested parties with " . . an opinion on an insurer's financial strength, including its operational performance and its ability to meet its obligations to policyholders." (Bouzouita and Young, 1998, p. 23).

As Cantor and Packer (1995) point out, credit rating agencies deal closely with issuers of corporate securities and use both quantitative and qualitative information when formulating their rating of a company's financial condition. The information used to establish such rankings is normally obtained from a combination of both public sources (e.g., the annual report and accounts) and private information (e.g., managerial statements). However, factors such as increased competition amongst credit rating agencies, the failure of those rating agencies to predict insolvency accurately, and pressure from issuers of securities have caused many commentators to question the credibility of financial ratings. ${ }^{1}$ This increased level of public concern about the activities of leading rating agencies is consistent with the results of a recent study by Ambrose and Carroll (1994) who report that external credit ratings are no better predictors of insurance company failure than conventional financial ratio analysis. This suggests that credit rating agencies may not possess unique and unbiased insights into the managerial systems and strategies employed by insurance companies. Consequently, we use United Kingdom

\footnotetext{
${ }^{1}$ In the early 1990s several US insurers, including Mutual Benefit and Universal Life, became insolvent. The credit rating agencies failed to predict these events (Carson and Scott, 1997).
} 
(UK)-based insurance company data relating to two of the most prominent credit rating firms A.M. Best and Standard and Poor (S\&P) - to examine: (i) the decision to voluntarily seek a rating, and (ii) the determinants of the letter ratings duly assigned.

There are two main reasons why we consider the UK to be a highly suitable environment within which to conduct this study. First, with life and non-life annual premiums in 1997 of $£ 110$ billion (US\$176 billion), the UK insurance market is the fifth largest in the world after the United States (US), Japan, Germany and France, and contributes substantially to the national economy (Association of British Insurers, 1998). As such, the results of this study should be comparable with evidence from other major insurance markets in which credit rating agencies are used such as those in the US and much of Western Europe. Second, like the US, the UK credit rating industry faces increasing institutional pressures, primarily in the form of stronger market competition. As a result, this study should provide a sound basis for comparison with prior US-based research (e.g., Brotman, 1989; Bouzouita and Young, 1998; Pottier, 1997, 1998; Pottier and Sommer, 1999) and, as mentioned earlier, serve as a stimulus for further credit rating-based research in other insurance markets.

By comparing the rating activities of A.M. Best and S\&P we are able to establish whether insurers' decisions to be rated and the determinants of the ratings themselves differ according to the methods used and range of activities traditionally undertaken by rating agencies. In particular, two major differences exist between the rating firms examined in this study. First, while S\&P have historically concentrated on rating individual debt issues and only begun ratings of insurance firms relatively recently, A.M. Best have always specialised in the assessment of insurance firms, ${ }^{2}$ and as such, the firm is often the preferred choice for insurance companies (Pottier and Sommer, 1999). Second, approximately 80 per cent of the ratings currently assigned to UK insurers by S\&P are based solely on publicly-available financial information, whereas A.M. Best bases all its ratings on a combination of publicly-available financial data and inside information provided during company visits. The financial tests performed by A.M. Best measure corporate financial performance in terms of profitability, liquidity and capital structure. The qualitative analysis includes an evaluation 
of an insurer's spread of risk, managerial expertise, adequacy of systems of internal control, and so on (Pottier, 1997). By comparing A.M. Best and S\&P data in this study we are therefore able to distinguish between the influence of public and non-public information on insurance companies' ratings.

Five motivations further underpin this study. First, an investigation into the impact of company-specific factors on financial distress prediction could help improve the understanding of business risks and may, therefore, have important policy-making implications (Borde et al, 1994). For example, if financial ratios are found to be good predictors of the financial strength of insurers then the use of credit rating agencies could, as in some countries (e.g., New Zealand), substitute for costly industry regulation. Second, insights into the determinants of credit ratings could assist industry regulators, policyholders, and investors when deciding whether or not to rely on the ratings assigned by credit rating firms. For instance, the absence of a linkage between ratings and important measures of financial risk (e.g., capital adequacy) could lead commentators to question the relevance and robustness of ratings assigned to insurance companies. Third, this study has the potential to shed light on the extent to which credit rating agencies are truly independent intermediaries or whether, instead, they are heavily influenced by institutional factors. For example, Klein (1992) reports evidence of growing public concern that credit rating agencies in the US appear to modify their ratings in response to pressure from the insurance industry, possibly in an attempt to improve policyholders' confidence after some high profile insurance company failures. Fourth, mutuals and non-publicly listed stock companies often play an important role in the insurance industry, but the value of these forms of organization cannot be ascertained from secondary markets. Credit rating agencies can therefore perform an important role for investors and policyholders in reporting on the financial standing of such companies and a better understanding of the factors which determine assigned ratings is likely to be of interest to stakeholders in non-listed insurance organizations. Fifth, the academic literature on the determinants of the financial strength of insurance companies, particularly outside of the US, is limited (Pottier and Sommer, 1999). Our research therefore contributes to the extant literature by

\footnotetext{
2 Although A.M. Best have rated the financial condition of US insurers since the 1920's (Cantor and Packer, 1995, 1997) the use of credit rating agencies outside North America is a more recent phenomenon; for example the firm
} 
presenting evidence about the factors that explain letter ratings assigned to UK-based direct insurers and provides a basis against which prior and future research can be compared and evaluated. The present study also improves upon previous US-based research in that it uses panel data from both the life and general insurance industries, thereby enabling robust estimates of cross-business-type effects to be derived.

The remainder of the paper is organized as follows. Section I provides background information on the use of credit ratings in insurance markets. Section II provides the framework and Section III discusses the research design. Section IV presents our empirical results, while Section V concludes the paper.

\section{Background}

The key function of credit rating agencies is to analyze and grade the financial strength of issuers of public securities, including insurers, and thereby assess companies' ability to fulfil their contractual obligations to consumers, creditors and other contracting constituents. ${ }^{3}$ Many researchers, such as Singh and Power (1992), Ambrose and Seward (1988), Ambrose and Carroll (1994) and Pottier $(1997,1998)$, have now acknowledged the important role played by credit rating agencies in alleviating the effects of information imperfections in insurance markets. As a consequence, accurate ratings help to prevent reckless risk-taking by insurers (Carson and Scott, 1997). In this regard, credit rating agencies have an important role to play in supplementing the solvency monitoring systems of insurance industry regulators, as well as enhancing the screening and monitoring activities of investment analysts and providers of corporate debt. Insurance firms use letter ratings to convey the adequacy of their financial condition to a broad group of potential users, including investors, policyholders, industry regulators and brokers. Strong ratings can also

only began rating UK insurers in the 1980s.

${ }^{3}$ The salient difference between insurance company ratings and corporate bond ratings is that with the former the ability to meet policyholders' claims is being assessed, whereas a bond rating applies to the security of a particular debt issue (Pottier and Sommer, 1999). While corporate ratings are carried out periodically (normally monthly) or after critical events (e.g., a catastrophe, corporate take-over, and so on), credit rating agencies monitor the effects of organizational and market developments and thus proceed on an ongoing basis (Cantor and Packer, 1995). 
provide insurers with better access to funds and enable them to reduce their market cost of capital (Pottier and Sommer, 1999).

Although the nature of the insurance company rating process is well-known, the extent to which interaction between credit rating agencies and the management of insurance companies enhances the robustness of the assigned rating is not well-established in the literature. For example, Ambrose and Seward (1988) find that financial ratios and assigned credit ratings provided by A.M. Best are equally efficient in predicting insurance company insolvency in the US. Their analysis therefore suggests that the supplementary inside (qualitative) information gathered by A.M. Best during their visits to insurance companies does not contribute any useful incremental information as to corporate financial condition and default risk. This result has potentially important implications for users of letter ratings (e.g., industry regulators, brokers) who employ credit rating agencies because they perceive their inside knowledge of managerial operations and systems to be both credible and valuable. The situation described above can be further exacerbated by a lack of public knowledge of the credit rating function. For example, Pottier (1997, p. 112) states that in the insurance industry “. . . rating agencies provide general information on the rating process [but] . . do not disclose the relative importance of the quantitative measures used."

\section{Framework}

The standard financial ratios used to assess the financial condition of insurance companies (and other financial services companies such as banks) normally focus on capital adequacy, management operations, earnings and liquidity (the so-called CAMEL criteria). These measures are incorporated in the Insurance Regulatory Information System (IRIS) of the US-based National Association of Insurance Commissioners (NAIC) to assist in solvency monitoring and control (Carson and Scott, 1997) as well as having been used in previous insurance industry studies as a basis for modelling the rating process (e.g., see Pottier, 1997). In this study, we therefore investigate the relation between seven corporate-specific variables - capital adequacy, 
profitability, liquidity, growth, company size, organisational form, reinsurance and business activity - and (i) insurance firms decision to volunteer for an external rating by A.M. Best or S\&P plus (ii) the determinants of the ratings themselves. Our framework, including the definition of variables, is considered in further detail below.

\section{A. Capital Adequacy}

Capital adequacy, which reflects an insurance company's exposure to operational and financial risks (e.g., poor underwriting results), is used in this study as an inverse measure of corporate financial leverage. As in Bouzouita and Young (1998), this is defined as the ratio of accumulated reserves to total assets $(R E S)$.

Cantor and Packer (1997) claim that high levels of leverage are frequently associated with increased uncertainty about a firm's ability to meet its claims. Borde et al. (1994, p. 181) share this view and state that risk “. . . can be influenced by the [insurance] company's degree of leverage, since leverage tends to magnify corporate returns or losses . . ". This in turn suggests that managers of highly leveraged insurers will not voluntarily secure a letter rating since a low rating is likely to exacerbate market uncertainties about their ability to meet contractual claims. In addition to measuring insurers' abilities to meet their fiscal obligations, the leverage proxy that we employ reflects an insurer's ability to write new business without undue financial strain on its capital base ${ }^{4}$. We contend that the higher the financial leverage, the greater the potential adverse effects of variations in underwriting performance and economic shocks on an insurer's ability to meet its commitments to policyholders and investors. That is, the larger an insurance firm's leverage ratio, the greater the risk of financial distress and default on claims. Some authors (e.g., Jensen, 1986) suggest, however, that high leverage (and the associated risk of default) can help in disciplining managers to act in the interests of fixed and residual claimants by preventing wasteful investment of free cash flow, and may therefore represent a positive attribute for insurers.

\footnotetext{
${ }^{4}$ Insurers, particularly those operating in life insurance markets, often incur high expenses when acquiring new business (e.g., in the form of medical expenses and sales commission). This can place a considerable strain on the insurer's ability to undertake new insurance unless there is an adequate capital base.
} 
Nonetheless, most prior studies (e.g., Brotman, 1989; Pottier, 1997, 1998) view high financial leverage as a negative feature of insurance companies' capital structure and we therefore predict a negative relation between leverage and both insurance company ratings and the likelihood of being rated, other things being equal.

\section{B. Profitability}

Like Bouzouita and Young (1998), we define profitability as the ratio of annual investment and underwriting income (net of expenses), plus unrealized capital gains, to statutory capital (PROFIT).

Examination of profitability enables financial analysts and industry regulators to assess an insurer's ability to invest annual surpluses efficiently in order to generate new business (Fok, et al., 1997; Bouzouita and Young, 1998; Pottier, 1998). In addition to providing an indication of an insurer's ability to remain as a going concern, measures of profitability also provide insights into management's ability to control expenses effectively and to set competitive rates of premium. Managers of profitable companies are expected to obtain a letter rating in order to enhance the corporate market profile and secure future new business. Moreover, Brotman (1989), Bouzouita and Young (1998), and others, contend that, in general, the higher the level of profitability, the better the insurance company's assigned credit rating. We therefore hypothesize that, other things being equal, there will be a positive linkage between insurance companies' profitability and (i) their propensity to seek a rating, as well as (ii) their assigned letter ratings.

\section{Liquidity}

The settlement of policyholders' claims as they fall due is a critical task for insurance companies (Brotman, 1989; Ambrose and Carroll, 1994; Borde et al., 1994) and so we treat liquidity as an explanatory variable in this study. Liquidity $(L I Q)$ is measured here by the ratio of current assets to current liabilities and therefore represents insurers' ability to fulfil their 
immediate obligations to policyholders in the event of claims (Pottier, 1998). It is plausible that managers of highly liquid insurers will be keen to signal their claims-paying ability to the markets through the rating process in order to promote their reputations for prudent management. In which case liquidity will be an important factor in the corporate decision to obtain a credit rating. If liquidity is too high, however, managers are provided with the means to invest in projects with negative net present values, reducing owners' wealth while simultaneously increasing managerial remuneration packages via the consumption of perquisites and the receipt of company size-related bonuses. Nonetheless, most prior studies (e.g., Carson and Scott, 1997; Bouzouita and Young, 1998) report the existence of a negative relation between insurance companies' liquidity risk and their credit ratings. As a consequence, we also predict that the better an insurer's liquidity, the higher will be both its credit rating and its probability of being rated, other things being equal.

\section{Growth}

Previous studies (e.g., Bouzouita and Young, 1998; Pottier and Sommer, 1998) have used the absolute change in annual reported surplus $(G R O W T H)$ to measure the prospective surety of policyholders' fixed claims in periods of adverse economic conditions.

Positive growth in annual surplus could be indicative of a favorable financial condition. Consequently, we predict that insurers achieving high growth in business are more likely to volunteer for a credit rating than insurers achieving low growth. However, significant new business growth could be due to low underwriting standards and under-pricing, and as such, result in greater uncertainty as to the adequacy of the insurer as a going concern. In other words, insurers that experience substantive growth in annual reported surplus could be subject to a high level of underwriting risk (Borde et al. 1994; Pottier, 1997). However, prior US-based insurance industry studies (e.g., Pottier and Sommer, 1998) find that business growth is associated with higher credit ratings because in practice it indicates the prospect of strong future cash flow performance and improved economic value. As a consequence, we predict that, other things being equal, growth in annual reported surplus will be positively related to the level of rating assigned to an insurer as well as the propensity to seek a rating. 


\section{E. Company Size}

In most studies of the insurance industry, company size is measured as the natural logarithm of total admitted assets because of the highly skewed distribution of total assets among firms operating in the insurance industry (Pottier and Sommer, 1997). Accordingly, this surrogate of insurance company size (LNSIZE) is also used here.

Bouzouita and Young (1998) suggest that company size is likely to be positively correlated with assigned credit ratings because, amongst other things, larger entities have access to a relatively wide pool of managerial expertise and are likely to realize economies of scale in their operations. Large insurers are also likely to have prominent market positions and public reputations for sound governance which prudent management will be keen to protect. These attributes, when combined with accumulated reserves, should enable large insurers to survive the impact of volatile underwriting climates and unfavorable economic conditions. Indeed, most prior studies (e.g., Pottier, 1997, 1998; Bouzouita and Young, 1998) have found that large insurers tend to have higher letter ratings than small insurers. As a consequence, we predict that large insurers are more likely to volunteer for a credit rating than small insurers. We also expect to find a positive relation between the size of insurers and their assigned credit rating, other things being equal.

\section{F. Organizational Form}

Adams (1995), Mayers and Smith (1994) and Pottier and Sommer (1997) contend that managerial decision-making in the insurance industry partly depends on whether a firm is a stock company (i.e., shareholder-owned) or a mutual (i.e., policyholder-owned). For instance, risktaking, investment and product-mix decisions are expected to vary between stock companies and mutuals as a direct result of their different ownership structures, contracting interests and internal governance. Therefore, our study also examines organizational form (OFORM), with the attribute treated as a dummy variable that takes the value 0 for a stock company and 1 for a mutual. 
In much of the insurance literature, mutual insurers are associated with precautionary managerial activities, behavior designed to promote policyholders' fixed claims in the long-term, whereas stock insurers are likely to engage in more risky activities in an attempt to maximize shareholders' short-term wealth (Adams, 1995). As a consequence, we predict that managers of mutual insurers will be more inclined to obtain a credit rating to promote their reputation for prudent management and protect their market share than will their counterparts in stock companies. What is more, a number of insurance industry studies, including Cox and Griepentrog (1988), suggest that high transaction and information costs, in conjunction with the indivisibility of investment assets, cause shareholders of stock companies to diversify their business risks less efficiently than conventional finance theory suggests. The studies claim that the existence of market frictions leave stock companies at greater risk of financial distress than mutual organizations. Indeed, Pottier (1997) cites evidence that in the US life insurance industry, mutuals are more highly rated than stock companies. We therefore predict that, all things being equal, mutual insurers are more likely to both seek an external credit assessment and receive a higher rating than are stock insurers.

\section{G. Reinsurance}

The likely effect of reinsurance on the rating assigned to an insurance company is not clear from the literature. By transferring risk to a third party, reinsurance can help to reduce uncertainty regarding the frequency and magnitude of future losses and enable a primary insurer to sustain an external economic shock (Adams, 1996). On the other hand, the insolvency of a reinsurance company could adversely affect the financial strength of the primary insurer, particularly in cases where the primary insurer was heavily reinsured. Clearly, the latter situation would complicate the assessment of a primary insurer's future financial condition and its ability to fulfil its obligations to policyholders, investors and others. In their recent US-based study, Pottier and Sommer (1999) did indeed find a negative relation between the amount of reinsurance undertaken and the letter rating assigned by leading agencies, suggesting that the insurance and investment markets view substantive reliance on reinsurance unfavorably. This reasoning suggests that, all else being equal, 
highly reinsured companies are less likely to volunteer for a credit rating than entities with less reinsurance. Additionally, for the insurance market as a whole, we expect that lowly reinsured insurance companies will be assigned higher letter ratings than highly reinsured insurance companies (and vice versa). As in Adams (1996), we define our reinsurance variable (REINS) as the ratio of annual reinsurance ceded over annual premiums written and hypothesize a negative relation between the variable and both the propensity to seek a rating and the rating itself.

\section{H. Business Activity}

Insurance companies may specialize in either short-term (e.g., vehicle insurance) or longterm business (e.g., life insurance). Alternatively, they may engage in a combination of both short and long-term operating lines and hence operate as composite insurers. Traditionally, long-term (e.g., life) insurance liabilities have been fairly predictable because of the application of actuarial principles in policy valuation. Moreover, the maintenance of statutory levels of solvency have helped to allay public concerns regarding life insurers' abilities to meet policyholders' future claims (Borde et al., 1994). This suggests that, other things being equal, life insurers are less likely to need a credit rating than are property-liability (general) insurers.

In recent years, however, unanticipated financial market risks, such as interest rate swings and foreign exchange rate movements, have shown that for many life insurers the actuarial value of their long-term assets and liabilities have been substantially mis-stated (Santomero and Babbel, 1997). The promotion of guaranteed annuity and investment contracts has also increased life insurers' exposure to insolvency risk relative to that faced by general insurers (Carson and Scott, 1997). Moreover, increased competition in life insurance markets has resulted in higher sales commission being paid to brokers and sales agents, which has in turn led to a strain being placed on the capital base of many life insurers (Adams, 1994). In the UK, the mis-selling of personal pensions has further increased many life insurers' liabilities and this has undoubtedly had adverse consequences for the assigned credit ratings of many life insurance companies (e.g., see Lees, 1997). In contrast, insurers writing short-term property-liability business have been somewhat better placed to adjust to unanticipated losses because of the ability to vary annual premiums, 
reduce operating costs and maintain volumes (e.g., through the use of new technology), and change underwriting terms at short notice. Additionally, composite insurance companies have been better able to manage their financial risks by holding a broad portfolio of insurance and investment products. This attribute should enable composite insurers, in particular, to diversify unanticipated movements in the value of their assets and liabilities across a wider pool of insurance risks than pure life insurers (Carson and Scott, 1997). Accordingly, we predict that, other things being equal, general and composite insurers will be more likely to volunteer for an external credit rating, and generally gain higher ratings, than pure life insurance companies. Line of business activity $(B U S)$ is incorporated in our model by the use of a variable taking the value 0 for life insurers, 1 for property-liability (general) insurers and 2 for composites.

\section{Data and Models}

Annual data were obtained for the 40 or so UK-based insurers that were rated by A.M. Best and the 25 UK-based insurers that were rated by S\&P between the years 1993 and 1997 inclusive ${ }^{5,6}$. Additionally, we collected a control sample of 28 UK-based insurers that were not rated by A.M. Best, S\&P, or any other credit rating agency over the five-year period studied. The period 1993-97 represents the earliest and latest years for which complete information on all A.M. Best-rated and S\&P-rated insurance companies were available at the time our study was carried out. The primary source of data that we used was the A.M. Best Insurance Companies Directory

\footnotetext{
${ }^{5}$ Reinsurance companies and Lloyds were excluded from our study because they are substantively different from direct insurers. For example, reinsurance companies do not write direct business and are therefore not subject to the same underwriting risks as conventional insurers. Lloyds, meanwhile, is not a corporate form of organization, but is instead a collection of underwriting interests (or Names). The Lloyds market also operates a three year accounting cycle to reflect the special (long-tail) nature of much of the risks that it insures/reinsures.

${ }^{6}$ The number of A.M. Best-rated companies varied across years as follows: 38 in 1997; 40 in 1996, 39 in 1995; 39 in 1994; and 39 in 1993. Our total A.M. Best sample thus represents an unbalanced panel of 195 company/year observations. Few UK insurers use the ratings of Moody's Investors Services, so tests involving this agency could not be undertaken.
} 
(1999). This was supplemented by data obtained from A.M. Best and S\&P International Insurer Ratings Lists, the DYP UK insurance companies' database and insurance company annual reports.

The empirical study is divided into two main parts. First, we estimate a 'rating decision' multinomial logit model to determine the main influences on an insurance company's decision to select either an A.M. Best rating, a S\&P rating or no rating. In this study, the dummy decision variable $(j)$ is set equal to 0 for non-rated insurers, 1 for S\&P-rated insurers and 2 for A.M. Bestrated insurers. The model to be estimated may be written in general form as:

$$
\text { Prob [choice j] }=\frac{e^{\alpha_{j}^{\prime}} x}{\sum_{j} e^{\alpha_{j}^{\prime}} x} \quad j=0,1,2
$$

where $\alpha_{j}^{\prime}$ is a vector of the parameters to be estimated for each $j$ and $x$ is the vector of independent variables, as discussed in Section II. These independent variables are the inverse measure of leverage $(R E S)$, profitability (PROFIT), liquidity $(L I Q)$, surplus growth (GROWTH), the natural logarithm of company size (LNSIZE), organisational form (OFORM), reinsurance (REINS) and business activity (BUS).

Second, we estimate 'rating determination' ordered probit models (with sample selection) for the A.M. Best-rated and S\&P-rated insurance companies separately. Insurance company ratings are ordinal measurements and, as such, their analysis necessitates the estimation of an ordered probit model, as developed by McKelvey and Zavoina (1975). This type of regression model was also used by Pottier and Sommer (1999). However, since A.M. Best and S\&P do not rate the full population of UK insurers, but rather only those companies applying voluntarily for a letter rating, our data set is potentially subject to self-selection bias (Greene, 1999). We control for this by extending the standard sample selection model of Heckman (1979) to the ordered probit model in the manner prescribed by Durbin and Rivers (1990) and Greene (1999). In this modified model, the ordinal random variable is assessed for self-selection bias by testing the correlation ( $\rho$ ) between the error terms in a 'rating decision' probit model and the 'rating 
determination' ordered probit model. The null hypothesis that selection bias does not exist is then $\rho=0$.

For each rating agency, the estimation is conducted in two stages. First, we estimate a 'rating decision' probit equation, with the dummy dependent variable set equal to 0 for non-rated insurance companies and equal to 1 for rated insurance companies. Second, we estimate the 'rating determination' ordered probit equation, with a coded value for the credit rating employed as the ordinal dependent variable. In this second stage, the coefficients of both models (including $\rho)$ are re-estimated using a full-information maximum likelihood technique, which ensures that the correlation between the error terms in the two models is taken into account. In the estimation procedure, our absolute measured financial data were deflated by the relevant average annual retail price index (base year $=1993$ ) in order to counteract the effects of inflation. Insurers that were not assigned a rating for reasons such as a lack of information or insufficient operating experience were excluded from the study.

The 'rating decision' probit model and the 'rating determination' ordered probit model (with sample selection) may be written in general form as:

$$
\begin{aligned}
d_{i t}^{*} & =\alpha^{\prime} x_{i t}+u_{i t} \\
d_{i t} & =0 \text { if } d_{i t}^{*} \leq 0 \\
& =1 \text { if } d_{i t}^{*}>0 \\
y_{i t}^{*} & =\beta^{\prime} x_{i t}+e_{i t} \\
y_{i t} & =0 \text { if } y_{i t}^{*} \leq \mu_{0} \\
& =1 \text { if } \mu_{0}<y_{i t}^{*} \leq \mu_{1} \\
& =2 \text { if } \mu_{1}<y_{i t}^{*} \leq \mu_{2} \\
& =3 \text { if } y_{i t}^{*}>\mu_{2}
\end{aligned}
$$




$$
\begin{aligned}
& u_{i t}, e_{i t} \sim N(0,0,1,1, \rho) \\
& {\left[y_{i t}, x_{i t}\right] \text { is observed if and only if } d_{i t}=1}
\end{aligned}
$$

In these models, the latent variables, $d^{*}$ and $y^{*}$, are continuous, unobserved variables: $d^{*}$ may be interpreted as the propensity to obtain a rating, while $y^{*}$ represents the propensity to be assigned a particular rating. The binary variable, $d$, equals 0 for an insurer that has no rating and 1 for an insurer with a rating. The ordinal variable, $y$, is coded on a four-point scale from 0 to 3 , where 0 represents the poorest condition and 3 superior financial strength ${ }^{7}$. In both models, $x$ represents a vector of independent variables and $\alpha^{\prime}$ and $\beta^{\prime}$ are the vectors of coefficients to be estimated. The two error terms, $u$ and $e$, are assumed to be normally distributed with means equal to zero, variances equal to one and a correlation coefficient equal to $\rho$.

The eight independent variables are predicted to have the same directional influence on both the decision to be rated and the ratings themselves, for the reasons set out in Section II, and so the equations to be estimated may be written in full as:

$$
\begin{aligned}
& d_{i t}^{*}=\alpha_{0}+\alpha_{1} R S_{i t}+\alpha_{2} \text { PROFIT }_{i t}+\alpha_{3} \text { LIQ }_{i t}+\alpha_{4} \text { GROWTH }_{i t}+\alpha_{5} \text { LNSIZE }_{i t}+ \\
& \alpha_{6} O_{F O R M} \\
& +\alpha_{7} \text { REINS }_{i t}+\alpha_{8} B U S_{i t}+u_{i t} \\
& y_{i t}^{*}=\beta_{0}+\beta_{1} R E S_{i t}+\beta_{2} \text { PROFIT }_{i t}+\beta_{3} \text { II }_{i t}+\beta_{4} \text { GROWTH }_{i t}+\beta_{5} \text { LNSIZE }_{i t}+\beta_{6} \text { OFORM }_{i t} \\
& +\beta_{7} \text { REINS }_{i t}+\beta_{8} B U S_{i t}+e_{i t}
\end{aligned}
$$

\footnotetext{
7 A.M. Best defines superior strength as A++/A+ (coded here as 3); excellent as both A (coded 2) and A- (coded 1); very good as B++ (also coded 1); and good, adequate or uncertain claims-paying ability as B+ and below (coded 0 ). S\&P define superior strength as AAA, excellent as AA+/AA/AA- and very good as A+ (all coded here as 3); good as A (coded 2) and A- (coded 1) and adequate or uncertain claims-paying ability as BBB+ and below (coded 0 ). The chosen codings reflect our judgement given the distributional properties of the observed data set.
} 


\section{Results}

\section{A. Descriptive Data}

Panel A of Table 1 reports the means and standard deviations of the independent variables used in the study. Separate figures are given for the A.M. Best-rated, S\&P-rated and non-rated companies in the sample. The most striking finding to emerge from an inspection of these figures is the large variation in surplus growth rates across the sample, particularly for the A.M. Bestrated insurance companies that have a coefficient of variation of 5.49. However, when the data for each A.M. Best-rated company were examined, it emerged that this figure was largely driven by an observation of 992 percent in 1997 for the newly-merged conglomerate of Royal Sun Alliance; removing this observation from the sample causes the coefficient of variation to fall to 2.3 .

Panel B of the table details the number of insurance firms obtaining each of our coded values of the A.M. Best and S\&P rating categories in all five years of the sample period. The results show that in all years, over 90 percent of the A.M. Best-rated insurers were given an A- or higher rating and categorised as 'excellent' or 'superior'. This proportion is higher than that found for US property-liability insurers by Pottier and Sommer (1999), who report that just over 72 percent of all A.M. Best-rated insurers in their study were classified as 'excellent' or 'superior' in 1996. The S\&P-rated insurers in our sample generally have substantially lower ratings than those assigned by A.M. Best; only 64 percent of the S\&P-rated insurers were assigned an A- or higher rating (roughly equivalent to a B+ A.M. Best rating) in 1993-95, rising to 88 percent in 1996-97. These proportions are lower than that those reported for US property-liability insurers by Pottier and Sommer (1999) who found that over 93 percent of the S\&P-rated insurers in their sample were assigned ratings of A- or higher. The figures in Panel B of Table 1 also reflect that the S\&P ratings for UK insurers changed more often than those of A.M. Best over the sample period.

Finally, Panel $\mathrm{C}$ of the table provides a matrix of Pearson correlation coefficients for all the independent variables included in the model. The correlation coefficients between pairs of 
independent variables are generally low (all are less than 0.53), which suggests that multicollinearity is unlikely to be a problem. Nevertheless, since collinearity can exist among more than two independent variables, we computed variance-inflation factors (VIFs) by regressing each independent variable in turn on all the others and then calculating $1 /\left(1-R^{2}\right)$. As the calculated VIFs are all less than 1.60 , we can be reasonably confident that multicollinearity is not a problem in this study ${ }^{8}$.

\section{B. The rating decision multinomial logit model}

The 'rating decision' multinomial logit estimation results are shown in Table 2. Interpreting the parameter estimates in this model is not straightforward, so we concentrate here on the statistical significance of the estimates and the marginal effects. Leverage, profitability, liquidity, company size and business activity prove to have statistically significant influences (at the five percent level, one tail) on the probability of selecting an A.M. Best rating. Similarly, profitability, liquidity, company size, reinsurance and business activity all have significant influences on the probability of selecting an S\&P rating. According to the marginal effects, an increase in RES (i.e., a decrease in financial leverage) reduces the probability of selecting an A.M. Best rating, but increases the probability of being non-rated or S\&P-rated. Increases in PROFIT, $L I Q$ or $B U S$ increase the probability of being A.M. Best-rated and reduce the probability of being non-rated or S\&P-rated, while increases in LNSIZE or REINS reduce the probability of being rated by either agency.

\footnotetext{
${ }^{8}$ See Gujarati (1995, pp. 338-339), for a discussion of 'rule-of-thumb' methods of detecting multicollinearity. Gujarati suggests that a VIF in excess of 10 would indicate a high degree of collinearity.
} 


\section{The rating decision probit models}

The 'rating decision' probit estimation results are summarised in Table 3. Three models are estimated: the first examines the decision to be A.M. Best-rated or non-rated, the second examines the decision to be S\&P-rated or non-rated and the third examines the decision to be rated (by A.M. Best or S\&P) or non-rated. The results are generally consistent with those obtained using the multinomial logit model shown in Table 2.

In the first model, leverage, profitability, liquidity, company size and business activity all have statistically significant influences (at the five percent level, one tail) on the decision to be rated by A.M. Best, while reinsurance and organizational form are not statistically significant. The estimated coefficients of LNSIZE and the inverse measure of leverage, RES, both have negative signs, suggesting that smaller insurance companies with higher leverage have a greater propensity to be A.M. Best-rated. This could be motivated by a desire among small insurers to increase their market profile and secure new business from larger, more established, operatives. The estimated coefficients of LIQ and PROFIT have positive signs, suggesting that insurance companies with higher levels of liquidity and profitability have a greater propensity to be A.M. Best-rated. The estimated coefficient of $B U S$ is also positive, which suggests that composite insurers have a greater propensity to be A.M. Best-rated than pure life or general insurers.

In the second model, profitability, liquidity, surplus growth, company size, reinsurance and business activity are all significant at the five percent level in a single tail test as influences on the decision to be S\&P-rated, while leverage is insignificant. The estimated coefficients of LNSIZE, LIQ and REINS all have negative signs, suggesting that smaller insurance companies with lower levels of liquidity and reinsurance will have a greater propensity to be S\&P-rated. The estimated coefficients of PROFIT, GROWTH and BUS are all positive, suggesting that faster-growing composite insurers with higher levels of profitability have a greater propensity to be S\&P-rated.

In the third model, leverage, profitability, surplus growth, company size, reinsurance and business activity are all significant influences on the decision to be rated (by either A.M. Best or $\mathrm{S} \& \mathrm{P})$. The estimated coefficients of RES, LNSIZE and REINS are negative, suggesting that smaller insurers with less reinsurance and more leverage have a greater propensity to be rated. 
The estimated coefficients of PROFIT, GROWTH and BUS are positive, suggesting that faster growing, composite insurers with higher levels of profitability are more likely to seek a rating. However, the estimated coefficient of LIQ, which was significantly positive in the A.M. Best regression and significantly negative in the $\mathrm{S} \& \mathrm{P}$ regression, is insignificant in the overall regression in a one tail test.

According to Pottier and Sommer (1999), the main influence on an insurers' decision to be rated is likely to be uncertainty, as insurance firms often seek a rating in order to reduce market uncertainty about their value and/or chances of insolvency. Our results tend to support this view. In particular, it is plausible that smaller insurers with relatively high levels of financial leverage and profitability may be regarded as less secure in their going concern status by industry regulators, potential investors and customers, and might, therefore, be more likely to seek a rating than large insurers.

The other statistics listed in Table 3 include a $\chi^{2}$ statistic for testing the null hypothesis that the regression coefficients (excluding the intercept term) are all zero. The $\chi^{2}$ values of 368.7, 196.4 and 327.5 respectively allow us to reject this hypothesis. The Kullback-Leibler $R^{2}$ values of $0.81,0.44$ and 0.58 suggest reasonably good fits ${ }^{9}$. Finally, from the cross-tabulation of actual and predicted values of the rating decision dummy variable, it can be seen that the estimated models correctly predict the A.M. Best rating decision in 317 out of the 335 cases, the S\&P rating decision in 228 out of 265 cases and the overall rating in 408 out of 460 cases.

\section{The rating determination ordered probit models}

The results obtained from estimating the 'rating determination' ordered probit model with sample selection are shown separately for the A.M. Best-rated and S\&P-rated samples in Table 4. In the A.M. Best regression, just three out of the seven independent variables included in the model have statistically significant effects on the assigned rating, namely profitability, liquidity and organizational form, all of which have the expected positive signs. The results thus enable us to conclude that mutual insurance companies with higher-than-average levels of profitability and

\footnotetext{
${ }^{9}$ The Kullback-Leibler $R^{2}$ is a measure of goodness-of-fit relative to a model with just a constant term.
} 
liquidity tend to have higher A.M. Best ratings. Of the other independent variables, business growth, company size, business activity and reinsurance all have the expected signs, but are not significantly different from zero at the 5 percent level (in one-tailed tests). The inverse measure of leverage, RES, has an unexpectedly negative sign and is insignificant. The estimate of the error correlation coefficient, $\rho$, is 0.75 with a standard error of 0.31 . This suggests that selection bias is present in our sample of A.M. Best-rated companies and justifies the application of the ordered probit model with selection.

In the S\&P regression, only two of the six independent variables have significant influences on the assigned rating, these being leverage and liquidity. The inverse measure of leverage RES has an unexpectedly negative sign, while liquidity has the expected positive sign. Of the other independent variables, profitability and business activity have positive signs as predicted, while company size and reinsurance have unexpected negative and positive signs respectively. The estimate of the error correlation coefficient, $\rho$, is only 0.06 with a standard error of 1.66 , suggesting that selection bias is not present in the sample of S\&P-rated insurance companies.

In interpreting the ordered probit results, it is important to emphasize that the coefficients are not the same as the marginal effects. In our models, where we assume a normal distribution and in which $y$ can take on four values $(0,1,2$ or 3$)$, we can write the probabilities $(P)$ associated with each $y$-value as:

$$
\begin{aligned}
& P(y=0)=\Phi\left(-\beta^{\prime} x\right) \\
& P(y=1)=\Phi\left(\mu_{1}-\beta^{\prime} x\right)-\Phi\left(-\beta^{\prime} x\right) \\
& P(y=2)=\Phi\left(\mu_{2}-\beta^{\prime} x\right)-\Phi\left(\mu_{1}-\beta^{\prime} x\right) \\
& P(y=3)=1-\Phi\left(\mu_{2}-\beta^{\prime} x\right)
\end{aligned}
$$

where $\Phi$ is the cumulative normal distribution function. The marginal effects are then given by:

$$
\frac{\partial P(y=0)}{\partial x}=-\varphi\left(\beta^{\prime} x\right) \beta
$$




$$
\begin{aligned}
& \frac{\partial P(y=1)}{\partial x}=\left[\varphi\left(-\beta^{\prime} x\right)-\varphi\left(\mu_{1}-\beta^{\prime} x\right)\right] \beta \\
& \frac{\partial P(y=2)}{\partial x}=\left[\varphi\left(\mu_{1}-\beta^{\prime} x\right)-\varphi\left(\mu_{2}-\beta^{\prime} x\right)\right] \beta \\
& \frac{\partial P(y=3)}{\partial x}=\varphi\left(\mu_{2}-\beta^{\prime} x\right) \beta
\end{aligned}
$$

where $\varphi$ is the standard normal density function. These partial derivatives were calculated for each independent variable in our two models and the results are shown in the bottom half of Table 4. In these models, with four $y$-categories, it is likely that the marginal effects will have opposite signs to those of the coefficients for $y=0$ and $y=1$, but the same signs for $y=2$ and $y=3$.

In both the A.M. Best and S\&P models, we find that an increase in PROFIT, LIQ or BUS will reduce the probability of being assigned a 0 or 1 coded ('low') rating and increase the probability of being assigned a ('high') 2 or 3. However, Table 4 also shows that, in both models, a higher value of RES (i.e., lower financial leverage) increases the probability of being assigned a 0 or 1 rating and reduces the probability of a 2 or 3 . The two models differ with respect to the effects of a change in company size and reinsurance. For the A.M. Best-rated insurance companies, an increase in LNSIZE or a decrease in REINS will increase the probability of being assigned a 0 or 1 rating and reduce the probability of a 2 or 3 while exactly the opposite applies to the S\&P-rated insurance companies. Finally, a change in OFORM from stock to mutual will reduce the probability of being assigned an A.M. Best-rating of 0 or 1 and increase the probability of a 2 or 3 .

The other statistics listed in Table 4 include Chow test results $(F=0.18$ and 0.32 respectively), which do not allow us to reject the hypothesis of temporal stability over the five years of the study ${ }^{10}$. Finally, an inspection of plots of the residuals on LNSIZE revealed no evidence of heteroskedasticity. To test this further, Breusch-Pagan $\chi^{2}$ statistics were calculated

\footnotetext{
${ }^{10}$ The use of pooled cross-section and time-series data is justifiable if there is both temporal and cross-sectional stability. With only five years of observations and seven independent variables, it is not possible to test for crosssectional stability, but we test for temporal stability by estimating the rating decision model for the first and second halves of the period 1993-97 and then calculating the Chow F statistic.
} 
after first regressing the squares of the standardized residuals on all the independent variables included in the two models. The calculated values of 7.96 and 5.89 (compared with a critical value of 14.07 at the five percent level of significance) confirm that the hypothesis of homoskedasticity cannot be rejected.

\section{Conclusions}

This is the first study to investigate the rating decision by UK insurance companies using logit and probit models that control for self-selection bias, and the first to focus specifically on credit ratings assigned to life, property-liability and composite insurance companies by A.M. Best and S\&P. Our approach is justified by the finding of a statistically significant degree of correlation between the error terms in the A.M. Best 'rating decision' and 'rating determination' models.

Our first main finding is that the decision to be rated by either A.M. Best or S\&P is positively related to an insurer's profitability, leverage and surplus growth, and negatively related to company size and the extent of reinsurance. We also find that composite insurers have a greater propensity to obtain a rating than pure life insurers or general insurers. These results lend some support to the view expressed by Pottier and Sommer (1999 that insurers frequently seek to obtain ratings in order to resolve ex ante uncertainty about their levels of financial risk and solvency. However, there are some differences in the determinants of the decision for insurers to be A.M. Best-rated or S\&P-rated. For example, insurance companies with higher levels of liquidity are more likely to select an A.M. Best rating and less likely to select an S\&P rating. Also, the results of estimating the multinomial logit model suggest that a decrease in leverage will reduce the likelihood of selecting an A.M. Best rating, but increase the probability of selecting a S\&P rating. Similarly, an increase in profitability will increase the probability of selecting an A.M. Best rating and reduce the probability of selecting an S\&P rating. These observations imply that insurance company managers may be more open to a visit by A.M. Best representatives when financial conditions are good than when they are relatively less favorable. 
Our second major finding concerns the ratings assigned by A.M. Best and S\&P. We find that the ratings assigned by A.M. Best are related to profitability, liquidity and organizational form. In particular, we have strong evidence to support the hypothesis that higher levels of profitability and liquidity lead to higher A.M. Best ratings and that mutual insurers tend to have higher A.M. Best ratings than stock insurers. This latter finding lends support to the view expressed by Adams (1995) that mutual insurers tend to engage in more precautionary managerial behavior and less risk-taking than do stock insurers, who face market pressures to maximize shareholder wealth. Although not statistically significant, our estimates of the coefficients for company size, reinsurance and business activity have the expected signs and so lend weak support to the hypotheses that larger companies with less reinsurance will have higher ratings, and that general and composite insurers will have higher ratings than life insurers. However, the inverse measure of leverage, $R E S$, has an unexpectedly negative sign and is insignificant, a result that may cast doubt on the robustness and reliability of credit ratings.

Turning to the ratings assigned by $\mathrm{S} \& \mathrm{P}$, we find that the two significant determinants are liquidity and leverage. As with the A.M. Best ratings and in line with our prior expectations, a higher level of liquidity leads to a higher S\&P rating. Contrary to our expectations, however, we find a significant negative relation between RES and the S\&P rating, suggesting that insurers with higher financial leverage will be more likely to be assigned a higher S\&P rating. In terms, therefore, of the decision to seek an external credit assessment and, more markedly, the determinants of the ratings, a number of differences exist between the findings relating to A.M. Best and S\&P. Whether or not these variations in the results can be attributed directly to differences in the historical nature of the two agencies' rating businesses, their different assessment procedures, or their sources of information, is a topic worthy of investigation in the future.

We believe that the results of our research have potentially important implications for firms operating in the insurance market as well as for policy-makers. For example, the evidence that mutual insurers are generally assigned higher ratings than stock companies suggests that certain publicly-traded insurance firms, in particular new entrants, might not possess sound financial strength and may require closer regulatory scrutiny than more established insurers. Also, 
the finding that liquidity has a significantly positive effect on ratings assigned by both firms should provide a measure of confidence in the robustness of the ratings to industry regulators, policyholders and investors in the UK, and might imply that such ratings could eventually play a role in substituting for costly industry regulation. From the point of view of UK insurance firms considering applying for an external credit assessment, the most important findings of this study are that, although the factors influencing the decision to be rated by A.M. Best or S\&P are broadly the same, a degree of variability exists in the variables which influence the actual ratings themselves. Insurance company managers and other parties (e.g., industry regulators) should be aware of this when contemplating whether to seek such a rating and which agency to choose for the assessment.

Whilst we believe that this study fills an important gap in the literature about players in the important UK insurance market, we acknowledge that interpretation of the results of this study should be tempered by inherent limitations in the research design, such as the use of a relatively small sample size compared with US studies. However, we have attempted to derive robust results, for example, through the use of panel data and by employing the ordered probit model in a form which takes full account of possible self-selection bias. In conclusion, we hope that this study will stimulate more research into the impact of company-specific factors on the financial strength of insurance firms and indeed, the likelihood of financial distress in the vitally important financial services sector as a whole.

\section{References}


Adams, M.B., 1994, "Some Thoughts on the Development and Structure of the New Zealand Life Insurance Industry", Journal of the Institute of Actuaries (December), 573-588.

Adams, M.B., 1995, "Balance Sheet Structure and the Managerial-Discretion Hypothesis:

An Exploratory Empirical Study of New Zealand Life Insurance Companies," Accounting and Finance (May), 21-45.

Adams, M. B., 1996, “The Reinsurance Decision in Life Insurance Firms: An Empirical Test of the Risk-Bearing Hypothesis", Accounting and Finance (May), 15-30.

Ambrose, J.M. and J.A. Seward, 1988, "Best's Ratings, Financial Ratios and Prior Probabilities in Insolvency Prediction," The Journal of Risk and Insurance (June), 229-244.

Ambrose, J.M. and AM Carroll, 1994, "Using Best's Ratings on Life Insurer Insolvency Prediction," The Journal of Risk and Insurance (June), 317-327.

Association of British Insurers, 1998, Insurance: Facts, Figures and Trends, London: ABI.

Best, A.M., 1999, Insurance Companies Directory, Oldwick, NJ: A.M. Best.

Borde, S.F., K. Chambliss and J. Madura, 1994, "Explaining Variation in Risk Across Insurance Companies," Journal of Financial Services Research (September), 177-191.

Bouzouita, R. and A.J. Young, 1998, “A Probit Analysis of Best Ratings," The Journal of Insurance Issues (Spring), 23-34.

Brotman, B.A., 1989, "Reliability of Best's Insurer Ratings Using Financial Information Published in the Annual Report," Journal of Insurance Issues and Practices (Spring), 58-70.

Cantor, R. and F. Packer, 1995, "The Credit Rating Industry," The Journal of Fixed Income (December), 10-34.

Cantor, R. and F. Packer, 1997, "Differences of Opinion and Selection Bias in the Credit Rating Industry," The Journal of Banking and Finance (October), 1395-1417.

Carson, J.M. and W.L. Scott, 1997, "Life Insurers and the "Run on the Insurer" Exposure," Journal of the American Society of CLU \& ChFC (March), 44-48.

Cox, L.A. and G.L. Griepentrog, 1988, "Systematic Risk, Unsystematic Risk, and PropertyLiability Rate Regulation," The Journal of Risk and Insurance (December), 606-627. 
Datta, P. and N.A. Doherty, 1990, "The Effects of Organizational Form on Capital Structure: The Case of Stock and Mutual Property-Liability Insurance Firms." In Risk, Information and Insurance, H. Lonberge (ed.), Norwell, MA: Kluwer Academic Publishers.

Durbin, J.A. and D. Rivers, 1990, "Selection Bias in Linear Regression, Logit and Probit Models", in J. Fox and J.S. Long, Modern Methods of Data Analysis, Newbury Park, CA: Sage Publications.

Fok, L.Y., W.M. Fok, P.P. Wei and S.M.L. Lee, 1997, “ The Effects of Firm Size on Risk and Profitability of the Property and Casualty Insurance Industry", The Journal of Insurance Issues (Spring), 25-36.

Greene, W.H., 1999, Econometric Analysis, $2^{\text {nd }}$ Edition, Englewood Cliffs, NJ: Prentice-Hall.

Gujarati, D.N., 1995, Basic Econometrics, $3^{\text {rd }}$ Edition, New York, McGraw-Hill.

Heckman, J., 1979, "Sample Selection Bias as a Specification Error," Econometrica, (47), 153-161.

Holthausen, R.W. and R. W. Leftwich, 1986, "The Effect of Bond Rating Changes on Common Stock Prices," Journal of Accounting and Economics (September), 57-89.

Jensen, M.C., 1986, "Agency Costs of Free Cash Flow, Corporate Finance and Takeovers," American Economic Review: Papers and Proceedings, (July), 323-329.

Klein, R.W., 1992, Insurance Company Rating Agencies: A Description of their Methods and Procedures, Washington DC: National Association of Insurance Commissioners.

Lees, M., 1997, “A Year of Consolidation”, Money Management, (December), 39-53.

Mayers, D. and C.W. Smith, 1994, "Managerial Discretion, Regulation and Stock Insurer Ownership Structure", Journal of Risk and Insurance, (December), 638-655.

McKelvey, R.D. and W. Zavoina, 1975, "A Statistical Model for the Analysis of Ordinal Level Dependent Variables”, Journal of Mathematical Sociology, 4, 103-20.

Pinches, G.E. and J.C. Singleton, 1978, "The Adjustment of Stock Prices to Bond Rating Changes," The Journal of Finance (March), 29-44.

Pottier, S.W., 1997, "Life Insurer Risk Characteristics and the Rating Process," The Journal Of Insurance Issues (Fall), 111-130.

Pottier, S.W., 1998, "Life Insurer Financial Distress, Best's Ratings and Financial Ratios," 
The Journal of Risk and Insurance (June), 275-288.

Pottier, S.W. and D. W. Sommer, 1997, “Agency Theory and Life Insurer Ownership Structure," The Journal of Risk and Insurance (December), 529-545.

Pottier, S.W. and D.W. Sommer, 1999, "Property-Liability Insurer Financial Strength Ratings: Differences Across Rating Agencies," The Journal of Risk and Insurance, 66 (December), (in press).

Santomero, A.M. and D.F. Babbel, 1997,"Financial Risk Management by Insurers: An Analysis of the Process," The Journal of Risk and Insurance (June), 231-270.

Singh, A.K. and M.L. Power, 1992, “The Effects of Best's Rating Changes on Insurance Company Stock Prices," The Journal of Risk and Insurance (June), 310-317.

Weinstein, M.I., 1977, “The Effect of a Rating Change Announcement on Bond Price," Journal of Financial Economics (December), 329-350. 


\section{Table 1 Descriptive Statistics for the Sample of UK Insurance Companies}

This table presents summary statistics for the sample of financial and insurance firm data used in the study. The sample consists of an unbalanced panel of 195 company/year observations for UK-based insurance companies rated by A.M. Best, 125 company/year observations for UK-based insurance companies rated by S\&P, and a further 140 company/year observations for UK non-rated insurance companies, all for the period 1993-97. Panel A provides descriptive data for the rated and non-rated insurers, while Panel B details the numbers of firms in each of A.M. Best's and S\&P's rating categories for the years 1993-97. Panel C shows the correlation matrix and varianceinflation factors (VIF) for the independent variables used in the study, calculated from the total sample of 460 observations. RES is the ratio of accumulated reserves to total assets (an inverse measure of financial leverage). PROFIT is the ratio of annual income plus unrealized capital gains to statutory capital. LIQ is the ratio of current assets to current liabilities. GROWTH is the absolute change in reported annual surplus. LNSIZE is the natural logarithm of total admitted assets. OFORM is a dummy variable that takes the value of 0 for a stock (shareholderowned) company and 1 for a mutual (policyholder-owned) company. REINS is the ratio of annual reinsurance ceded over annual premiums written. BUS is a dummy variable that takes the value of 0 for life insurers, 1 for general insurers and 2 for composites. $S D$ refers to standard deviation.

\section{Panel A: Key Summary Statistics for the Sample}

\begin{tabular}{lccccccc} 
& \multicolumn{2}{c}{ A.M. Best } & \multicolumn{3}{c}{ Standard and Poor } & \multicolumn{3}{c}{ Non-rated Companies } \\
Variables & Mean & SD & Mean & SD & Mean & SD & \\
\hline RES & 0.73 & 0.12 & 0.88 & 0.06 & & 0.90 & 0.09 \\
PROFIT & 0.33 & 0.11 & 0.08 & 0.05 & 0.07 & 0.08 & \\
LIQ & 2.32 & 0.84 & 1.43 & 0.29 & 1.77 & 0.90 & \\
GROWTH & 14.15 & 77.62 & 22.12 & 69.49 & 0.88 & 2.82 & \\
LNSIZE & 2.78 & 0.71 & 6.51 & 1.76 & 7.60 & 1.55 & \\
OFORM & 0.13 & 0.34 & 0.00 & 0.00 & 0.29 & 0.46 & \\
REINS & 0.27 & 0.23 & 0.23 & 0.14 & 0.31 & 0.39 & \\
BUS & 1.05 & 0.62 & 1.32 & 0.47 & 0.68 & 0.60 &
\end{tabular}


Panel B: A.M. Best and S\&P Ratings, 1993-97

Coded Rating Grade and Category ${ }^{a}$

No. of Firms

$\begin{array}{llllll}1993 & 1994 & 1995 & 1996 & 1997 & \text { Total }\end{array}$

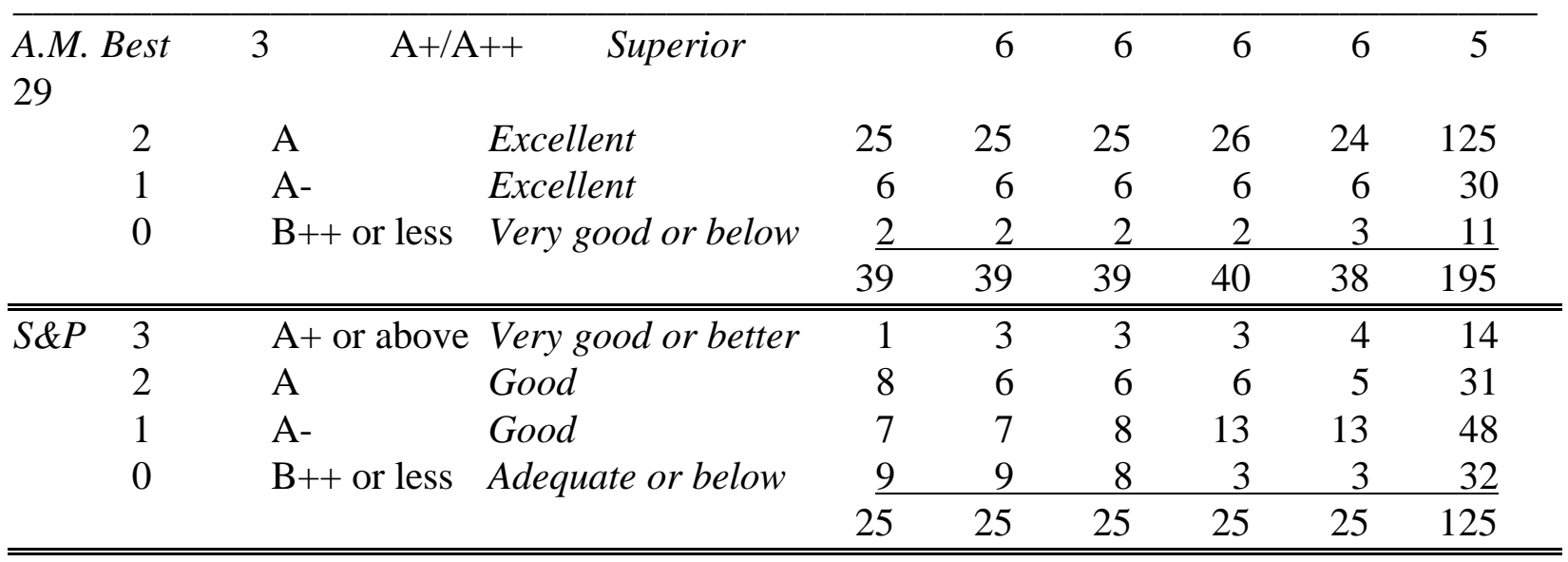

Panel C: Pearson Correlation Coefficient Matrix and Variance-Inflation Factors (VIFs)

VIFs

\begin{tabular}{lcccccccc}
\hline & & PROFIT & LIQ & GROWTH & LNSIZE & OFORM & REINS & BUS \\
\cline { 2 - 8 } RES & 1.58 & -0.52 & -0.16 & -0.01 & 0.34 & 0.08 & -0.05 & -0.27 \\
PROFIT & 1.59 & 1 & 0.25 & 0.03 & -0.26 & -0.20 & -0.11 & 0.12 \\
LIQ & 1.10 & & 1 & -0.01 & -0.08 & -0.10 & 0.09 & 0.16 \\
GROWTH & 1.28 & & 1 & 0.37 & -0.05 & -0.08 & 0.21 & \\
LNSIZE & 1.38 & & & 1 & 0.38 & -0.27 & -0.28 \\
OFORM & 1.35 & & & & 1 & -0.30 & -0.31 \\
REINS & 1.24 & & & & & 1 & 0.26 \\
BUS & 1.25 & & & & & & 1 \\
=======================================================
\end{tabular}

\section{Correlations}




\section{Table 2 The Rating Decision Multinomial Logit Model: Estimation Results}

This table shows the estimation results for the rating decision multinomial logit model, using data from our complete sample, which consists of an average of 92 UK insurance companies over five years (making 460 company/year observations in total). The first part of the table lists the parameter estimates and standard errors for the A.M. Best-rated and S\&P-rated insurance companies, while the second part shows the marginal effects for the A.M. Best-rated, S\&P-rated and non-rated insurers respectively. The final part of the table shows a $\chi^{2}$ goodness-offit statistic and a cross-tabulation of predicted and actual values of the rating decision dummy variable.

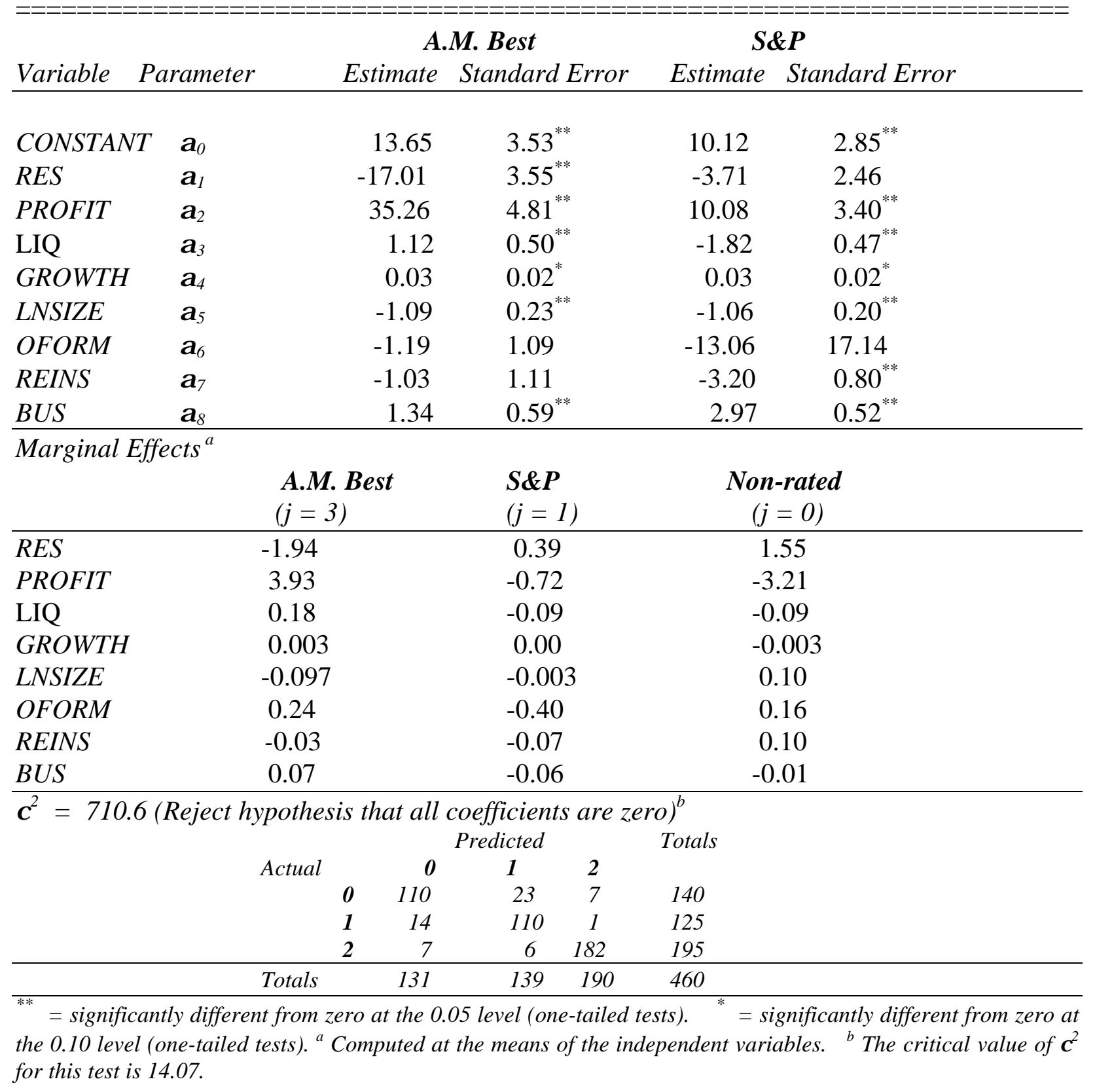




\section{Table 3 The Rating Decision Probit Models: Estimation Results}

This table shows the estimation results for the rating decision probit models. To obtain the A.M. Best estimates, data were used from a sample of an average of 39 A.M. Best-rated and 28 non-rated UK-based insurance companies over five years (making 335 company/year observations in total). To obtain the S\&P estimates, data were used from a sample of $25 \mathrm{~S} \& \mathrm{P}$-rated and the 28 non-rated UK-based insurance companies over five years (making 265 observations in total). To obtain the overall estimates, data were used from an average of 64 A.M. Best-rated and S\&P-rated UK-based insurance companies, together with the 28 non-rated companies over five years (making 460 observations in total). The first part of the table lists the parameter estimates and standard errors, while the second part shows a set of diagnostic statistics and cross-tabulations of predicted and actual values of the rating decision dummy variables. In the A.M. Best model, GROWTH proved to be highly insignificant $(t<0.5)$ and so has been omitted. In the S\&P sample, all insurers are stock companies, so the coefficient of $O F O R M$ could not be estimated.

\begin{tabular}{|c|c|c|c|c|}
\hline \multicolumn{2}{|c|}{$\begin{array}{l}\text { Model } \\
\text { Variable Parameter }\end{array}$} & \multirow{2}{*}{$\begin{array}{l}\text { 1. A.M. Best } \\
\text { Estimate } \\
2.95(1.61)^{*}\end{array}$} & \multirow{2}{*}{$\begin{array}{l}\text { 2. S\&P } \\
\text { Estimate } \\
6.15(1.65)^{* *}\end{array}$} & \multirow{2}{*}{$\begin{array}{l}\begin{array}{l}\text { 3. Overall } \\
\text { Estimate }\end{array} \\
5.41(1.22)^{* *}\end{array}$} \\
\hline CONSTANT & $\alpha_{0}$ & & & \\
\hline$R E S$ & $\alpha_{1}$ & $-6.80(1.75)^{* *}$ & $-1.77(1.51)$ & $-3.48(1.10)^{* *}$ \\
\hline PROFIT & $\alpha_{2}$ & $14.66(2.17)^{* *}$ & $5.20(1.87)^{* *}$ & $9.80(1.36)^{* *}$ \\
\hline$L I Q$ & $\alpha_{3}$ & $0.58(0.21)^{* *}$ & $-0.83(0.26)^{* *}$ & $-0.10(0.16)$ \\
\hline GROWTH & $\alpha_{4}$ & - & $0.16(0.06)^{* *}$ & $0.02(0.01)^{* *}$ \\
\hline LNSIZE & $\alpha_{5}$ & $-0.20(0.10)^{* *}$ & $-0.84(0.12)^{* *}$ & $-0.52(0.08)^{* *}$ \\
\hline OFORM & $\alpha_{6}$ & $-0.44(0.47)$ & - & $-0.44(0.35)$ \\
\hline REINS & $\alpha_{7}$ & $-0.62(0.53)$ & $-1.88(0.47)^{* *}$ & $-1.59(0.37)^{* *}$ \\
\hline$B U S$ & $\alpha_{8}$ & $1.14(0.36)^{* *}$ & $1.71(0.30)^{* *}$ & $1.18(0.20)^{* *}$ \\
\hline
\end{tabular}

Standard errors in parentheses

$\begin{array}{ccc}\text { Chi-squared test }: & \chi^{2}=368.7 \quad \chi^{2}=196.4 \quad \chi^{2}=327.5 \\ & (\text { Reject hypothesis that all coefficients are zero })^{a}\end{array}$

Kullback-Leibler $R^{2}: \quad R^{2}=0.81 \quad R^{2}=0.44$

Predicted and actual values of the dependent variable:

A.M. Best

Predicted Totals

$\begin{array}{lrrr}\text { Actual } & \boldsymbol{0} & \mathbf{1} & \\ \mathbf{0} & 132 & 8 & 140 \\ \mathbf{1} & 10 & 185 & 195 \\ \text { Totals } & 142 & 193 & 335\end{array}$

$S \& P$

Predicted Totals

Actual $00 \quad 1$

$\begin{array}{llll}0 & 119 & 21 & 140\end{array}$

$\begin{array}{lll}16 & 109 & 125\end{array}$

Totals $\quad 135 \quad 130 \quad 265$

\begin{tabular}{crrc} 
& \multicolumn{3}{c}{ Overall } \\
& Predicted & Totals \\
Actual & $\boldsymbol{0}$ & & $\mathbf{1}$ \\
$\mathbf{0}$ & 111 & 29 & 140 \\
$\mathbf{1}$ & 23 & 297 & 320 \\
Totals & 134 & 326 & 460
\end{tabular}

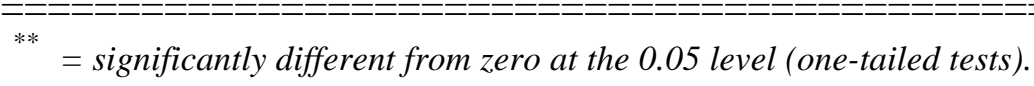


$* \quad$ significantly different from zero at the 0.10 level (one-tailed tests).
${ }^{a}$ The critical value of $\chi^{2}$ for this test is 14.07 .

\section{Table 4 The Rating Determination Ordered Probit Models with Sample Selection: Estimation Results}

This table shows the estimation results for the rating determination ordered probit model with sample selection. Data were derived from a sample of 28 non-rated, an average of 39 A.M. Best-rated and 25 S\&P-rated UK-based insurance companies over five years (making 335 observations in total for the A.M. Best estimation and 265 for the S\&P estimation). The first part of the table provides the parameter estimates and standard errors, while the second part summarizes a set of diagnostic statistics and the marginal effects for each independent variable. GROWTH proved to be highly insignificant in both models and so has been omitted from the models. The coefficient of OFORM cannot be estimated in the S\&P model because all of the S\&P-rated companies in the sample are stock companies.

\begin{tabular}{|c|c|c|c|c|c|c|c|c|}
\hline \multirow[b]{2}{*}{ Variable } & \multirow[b]{2}{*}{ Parameter } & \multicolumn{3}{|c|}{ A.M. Best } & \multicolumn{4}{|c|}{$S \& P$} \\
\hline & & \multicolumn{2}{|c|}{ Estimate $S t$} & Standard Error & \multicolumn{3}{|c|}{ Estimate } & Standard Error \\
\hline CONSTANT & $\Gamma \quad \beta_{0}$ & \multicolumn{2}{|c|}{0.40} & 1.15 & \multicolumn{3}{|c|}{10.25} & 3.93 \\
\hline$R E S$ & $\beta_{1}$ & \multicolumn{2}{|c|}{-1.16} & 1.24 & \multicolumn{3}{|c|}{-13.33} & $3.74^{* *}$ \\
\hline PROFIT & $\beta_{2}$ & \multicolumn{2}{|c|}{2.55} & $0.97^{* *}$ & \multicolumn{3}{|c|}{5.05} & 5.80 \\
\hline LIQ & $\beta_{3}$ & \multicolumn{2}{|c|}{0.18} & $0.10^{* *}$ & \multicolumn{3}{|c|}{2.18} & $0.87^{* *}$ \\
\hline LNSIZE & $\beta_{5}$ & \multicolumn{2}{|c|}{0.11} & 0.11 & \multicolumn{3}{|c|}{-0.17} & 0.38 \\
\hline OFORM & $\beta_{6}$ & \multicolumn{2}{|c|}{0.70} & $0.35^{\text {** }}$ & \multicolumn{3}{|c|}{-} & - \\
\hline REINS & $\beta_{7}$ & \multicolumn{2}{|c|}{-0.37} & 0.57 & \multicolumn{3}{|c|}{0.15} & 1.62 \\
\hline$B U S$ & $\beta_{8}$ & \multicolumn{2}{|c|}{0.03} & 0.26 & \multicolumn{3}{|c|}{0.12} & 1.28 \\
\hline Division & $\mu_{1}$ & \multicolumn{2}{|c|}{0.79} & $0.18^{* *}$ & \multicolumn{3}{|c|}{1.71} & $0.31^{\text {** }}$ \\
\hline & $\mu_{2}$ & \multicolumn{2}{|c|}{2.74} & $0.22^{* *}$ & \multicolumn{3}{|c|}{3.15} & $0.38^{* *}$ \\
\hline Error corr. & $\rho$ & \multicolumn{2}{|c|}{0.75} & $0.31^{* *}$ & \multicolumn{3}{|c|}{0.06} & 1.66 \\
\hline \multicolumn{2}{|l|}{ Chow tests: } & \multicolumn{3}{|c|}{$F=0.18$} & ftempo & $\begin{array}{l}F= \\
\text { ral stab }\end{array}$ & $\begin{array}{l}0.32 \\
\text { ility in }\end{array}$ & ( either model) ${ }^{a}$ \\
\hline Breusch-Pag & gan tests: & $\begin{array}{l}\chi^{2}= \\
\text { (Cannc }\end{array}$ & $\begin{array}{l}7.96 \\
\text { ot rejec }\end{array}$ & ct hypothesis o. & homosh & $\begin{array}{l}\chi^{2}= \\
\text { kedastic }\end{array}$ & $\begin{array}{l}5.89 \\
\text { ity })^{b}\end{array}$ & \\
\hline Marginal Eff & ffects: & & & & & & & \\
\hline & & A.M. Be & est Ratin & & & $S \& P R$ & ating & \\
\hline & 0 & 1 & 2 & 3 & 0 & 1 & 2 & 3 \\
\hline RES & 0.14 & 0.21 & -0.12 & -0.23 & 2.86 & 1.60 & -3.80 & -0.66 \\
\hline PROFIT & -0.31 & -0.46 & 0.26 & 0.50 & -1.08 & -0.60 & 1.43 & 0.25 \\
\hline$L I Q$ & -0.02 & -0.03 & 0.02 & 0.04 & -0.47 & -0.26 & 0.62 & 0.11 \\
\hline LNSIZE & -0.01 & -0.02 & 0.01 & 0.02 & 0.04 & 0.02 & -0.05 & -0.01 \\
\hline OFORM ${ }^{c}$ & -0.08 & -0.13 & 0.07 & 0.14 & - & - & - & - \\
\hline REINS & 0.04 & 0.07 & -0.04 & -0.07 & -0.03 & -0.02 & 0.04 & 0.01 \\
\hline$B U S^{c}$ & -0.004 & -0.006 & 0.003 & 30.006 & -0.03 & -0.01 & 0.03 & 0.01 \\
\hline
\end{tabular}


results when the dummy variable changes by one unit. 